\title{
The changing face of southern New Zealand farming: opportunities of land use change
}

\author{
R.J. COPLAND ${ }^{1}$, D.R. STEVENS ${ }^{2}$ \\ ${ }^{1}$ Rabobank, P.O. Box 150, Gore. \\ ${ }^{2}$ AgResearch Invermay Research Centre, Puddle Alley Rd, Mosgiel. \\ Richard.copland@rabobank.com
}

\begin{abstract}
Southern New Zealand has seen major changes in land use in the past 20 years with the rise in dairy cows in milk from 149000 in 1994 to 682000 in 2010, while breeding ewe numbers have declined from 11.2 million to 7.3 million over the same period. The development of milking platforms with a significant need for winter dairy grazing has opened up many opportunities for sheep, beef and deer farmers in the region. The need to remain profitable, displacement of sheep to more marginal land, and social influences such as retaining family ownership have encouraged farmers to make the most of potential land-use change opportunities. Three case studies outline the changes made and potential profitability increases in dairy conversion, flexible sheep and beef operations and improved deer production, with cash surplus after expenses being more than doubled in each case.
\end{abstract}

Keywords: land use, profit, dairy, sheep, beef, deer.

\section{Introduction}

Southern New Zealand has seen a major change in farming over the past 20 years since the last conference in Gore in 1992. Successful enterprises that were highlighted at that conference were conversion to dairy (Kleyngeld \& Kleyngeld 1992), bull beef farming (McCraw 1992) and intensive sheep farming (Rolhoff 1992). Continued dairy conversions have been a feature of the change in the region as the number of dairy cows in milk has increased from 149000 in 1994 to 682000 in 2010 in Otago and Southland (Table 1). Sheep numbers have declined significantly (Table 1).

This changing face of land use from the early 1990s has seen significant opportunities arise. The most significant of these has been the development of dairy farms as milking platforms, thus requiring a separate source of feed for winter, and for raising young stock. In a survey of 204 farmers in Southland, 78\% wintered on crops or pasture, the majority of those were away from the home farm (Tarbotton et al. 2012). This translates into a potential off-farm winter feed requirement for up to 530000 dairy cows.

Pittaway et al. (1992) noted that Southland farmers perceived risk as a major threat to their business.
Their response to risk was to consolidate land holding, potentially expanding where they could, and integrating new technologies into their farming business to specialise and intensify their production. Approximately $50 \%$ of farmers had purchased more land, diversified or developed land in the previous 20 years. Fifty percent or less of those farmers would diversify or develop land again, but $75 \%$ said they would purchase more land, indicating their preference for managing risk. Many technology-based strategies were employed, as farmers used specialisation and intensification as a risk management strategy. Overall they were less likely to accept some potential risk reducing strategies such as alternative asset ownership structures. So has it changed since then?

This paper outlines thoughts on the potential drivers of change in the region and identifies opportunities that have been taken up and how have they added to profitability. We examine changes in sheep and beef, deer and dairy enterprises using three case studies.

\section{Drivers of Change}

Eastern Southland/West Otago remains a very competitive place in which to farm. Profitability in this region has always been some of the best in the country (Ministry for Primary Industry 2012), and locally a number of farmers continue to challenge expectations of profit and performance. With product prices overall much better in recent years (Davison 2012), why do these farmers continue to strive to improve performance and resource use efficiency?

While a number of factors are driving change, the common theme is generating more profit per hectare. The reasons farmers are chasing this are varied; in some cases it is about growing their business, for others it is retaining family on the land, but it can be simply the new challenge or satisfaction gained from developing a new farm system.

\section{Increasing Land values}

High local rural land values (dry stock/cropping up to $\$ 20000 /$ ha, dairy up to $\$ 40000 / \mathrm{ha}$ ) are pushing those who want to expand their business to be consistently in the top $25 \%$ of farmers for profitability. Without 
performance at these levels it is difficult to outbid the neighbour for this land. Purchasing the 200 acres next door is no mean feat when it may cost between $\$ 1.2$ $\$ 1.6$ million. But to stay ahead of the ever increasing "economic farm size" this remains a goal for many people.

\section{Retaining family on the Land}

The average land holding in the district is in the 240300 hectare range. Given average profitability levels, a traditional sheep \& beef property may not be able to support more than one generation on the family farm without considerable off-farm income. However, the return from dairying can achieve this, and is often the main reason cited for conversion to dairying. This is consistent with the individual ownership, family-based model of Southland farmers described by Pittaway et al. (1992). For this reason dairy conversion, a more efficient resource use in many situations, will continue. Also of note, the next generation are returning to the farm with different skill sets and their eyes open. Many have had work experience in a diverse range of professions, such as builders, bankers, engineers and rural service agents, and want to stamp their mark on the property when they come home. They are open to change, and challenge the status quo.

\section{Demand from a feed-hungry dairy industry}

Expansion of the dairy herd (Table 1) has increased the opportunities for other farmers in the region. Increasingly, grain, whole crop and grass silage sales, and dry stock grazing now make up a proportion of income on a sheep farm. In many situations these enterprises complement the existing production system, enabling higher returns to be made from both. An added bonus is that, being a local market, prices are not affected by the exchange rate.

\section{Redistribution of livestock to the hill country}

As dairying has marched across the plains we have seen traditional intensive finishing farmers move to hill country. Many are not happy to accept the historic expectation of these properties as simple store lamb propositions, and embark on extensive development programmes soon after their arrival. Their aim is to develop "finishing pastures like they used to have", only on the hill. Anecdotally, this has been highly successful, with many, in fact, claiming the ability to finish livestock faster on hill country than on the flats, albeit at a lower stocking rate.

It is not only sheep and cattle that are moving. Deer are also on the move as numbers have reduced (Table 1), with breeding hinds in particular, moving further into the back country, where they hold a natural production advantage over sheep due to their closer fit of feed demand with pasture supply.

\section{Case Study 1: Dairy Conversions}

Throughout the wider Otago Southland region dairy conversions have continued at a rate of around 30 per year. Some of these conversions are additions to existing units, some are runoff blocks, but many are occurring on sheep and beef properties. This type of dairy conversion is probably the ultimate example of increasing resource use efficiency. An efficient breeding ewe operation running 14 stock units $(\mathrm{su}) / \mathrm{ha}$, where hoggets are mated and all lambs are finished, may typically produce between 350 and $450 \mathrm{~kg}$ product/ ha made up of meat (carcass weight) and wool. The same hectare of land under dairy production requires a higher level of inputs, but produces 1000-1200 kilograms of milk solids, nearly three times as much. Where expensive land is the most limiting resource, conversion to dairy produces more product with a better cash return in most years (Table 2).

\section{Key improvements}

Southland dairy farmers operate a farm system that enables pasture to grow to its potential. Rotational grazing, maintaining pasture covers in the range where

Table 1. The changes in livestock numbers in Otago and Southland since 1994 (Statistics New Zealand 2012)

\begin{tabular}{|c|c|c|c|c|c|c|}
\hline \multirow[t]{2}{*}{ Numbers $(000)$} & \multicolumn{2}{|c|}{1994} & \multicolumn{2}{|c|}{2002} & \multicolumn{2}{|c|}{2010} \\
\hline & Otago & Southland & Otago & Southland & Otago & Southland \\
\hline Total Sheep & 7,636 & 7,851 & 6,121 & 5,951 & 5,323 & 4,597 \\
\hline Breeding Ewes & 5,376 & 5,867 & 4,230 & 4,538 & 3,795 & 3,492 \\
\hline Lambs & 5,754 & 7,245 & 5,180 & 6,149 & 4,733 & 5,019 \\
\hline Total Dairy & 82 & 114 & 205 & 356 & 262 & 599 \\
\hline Cows in milk & 62 & 87 & 151 & 262 & 214 & 468 \\
\hline Beef & 270 & 202 & 267 & 204 & 281 & 186 \\
\hline Beef Calves & 79 & 56 & 88 & 57 & 89 & 51 \\
\hline Deer & 91 & 184 & 197 & 352 & 169 & 246 \\
\hline Deer weaners & 28 & 57 & 85 & 147 & 70 & 104 \\
\hline
\end{tabular}


pasture growth is maximised (1500-2500 kg DM/ ha), destocking over winter, higher fertiliser inputs and standoff areas for wet conditions, all contribute to higher rates of growth when compared to a spring set-stocked breeding ewe system. Typically this results in greater pasture production under dairy (Dalley et al. 2012) than under sheep (Smith 2012).

Utilisation of pasture grown is also higher under dairy, through an improvement in matching stocking rate to the pasture growth curve, and greater use of supplements in the shoulders of the season (Holmes $\&$ Roche 2007). The dairy cow is also a much more efficient converter of grass to product, requiring approximately $12.5 \mathrm{~kg} \mathrm{DM} / \mathrm{kg}$ MS (Holmes \& Roche 2007) compared with approximately $25 \mathrm{~kg} \mathrm{DM} / \mathrm{kg}$ product for a sheep breeding and finishing property (10 $000 \mathrm{~kg} \mathrm{DM} / \mathrm{ha}$ utilised divided by $400 \mathrm{~kg}$ product/ ha). Combined, these three factors generate the additional product per hectare under dairying.

\section{Outcomes of implementing improvement strategies}

The conversion to dairy enabled an increase in saleable product and allowed for greater productivity of the land (Table 2). This created greater cash flow and net surplus than was able to be generated in the sheep operation (Table 2). Interestingly the actual return on capital is not significantly altered in this example and continues to support the findings of Pittaway et al. (1992) that family based objectives were a strong basis to decision making and risk management to ensure on-going farm ownership.

\section{Case Study 2: Improving sheep farm productivity}

The Eastern Southland Beef and Lamb Monitor Farm (2007-2010) was a 421 ha property, stocked at 11.4 su/ha

Table 2. A comparison of sheep and dairy farm performance before and after conversion to dairy, using current status quo pricing in southern New Zealand

\begin{tabular}{lll}
\hline & Sheep & Dairy \\
\hline Land area & $240 \mathrm{ha}$ & $240 \mathrm{ha}$ \\
Stock units & 3,000 & \\
Cows in milk & & 640 \\
Production indicators & $140 \%$ lambing & $250,000 \mathrm{~kg} \mathrm{MS}$ \\
& $381 \mathrm{~kg}$ product/ha & $1040 \mathrm{~kg}$ product/ \\
& & ha \\
Gross income & $\$ 400,000$ & $\$ 1,637,500$ \\
Farm working expenses & $\$ 240,000$ & $\$ 1,050,000$ \\
Debt servicing & $\$ 250 / \mathrm{su}$ & $\$ 20 / \mathrm{kg} \mathrm{MS}$ \\
& $\$ 52,500$ & $\$ 350,000$ \\
Earnings before tax & $\$ 107,500$ & $\$ 237,500$ \\
Total farm capital & $\$ 4,200,000$ & $\$ 10,100,000$ \\
Return on capital & $2.6 \%$ & $2.4 \%$ \\
\hline
\end{tabular}

at the beginning of the programme and achieving a cash surplus of $\$ 269 /$ ha. Pasture quality and utilisation were identified as key issues resulting in low lamb growth rates in summer. This led to a cycle where lambs remained on the property until May, reducing the amount of pasture available for autumn and winter grazing. The result was reflected in lower than potential scanning. Low lamb numbers born then reduced the capacity to control the spring surplus, creating a pasture quality problem, therefore continuing the cycle.

\section{Key improvements}

The target of improving feed quality was achieved by restricting late spring pasture cover to 1100 to 1400 $\mathrm{kg} \mathrm{DM} / \mathrm{ha}$. This would ensure that the late spring surplus was controlled and summer quality would be maximised. With improved summer feed quality available, the average slaughter date of lambs would be bought forward, ensuring increased lambing percentage to better utilise the spring feed supply.

\section{Strategies to address production and profitability}

The strategies chosen were based on three key tenets.

1. Base decisions on profit, not production, and on available options at the time, making them potentially different each time a decision is made throughout the year.

2. Know the feed supply and make decisions ahead of the market, principally to achieve the spring pasture goals.

3. Create a balance of $70-80 \%$ capital stock and 20 $30 \%$ trading and cropping options to maintain the productivity base but have flexibility to meet the pasture goals.

In the first spring, the major aim was to break out of the predominant cycle. Four management options were implemented. Ewes and lambs were bought to add extra

Table 3. Sheep farm performance before and after farm changes to utilise the spring pasture surplus and increase summer feed quality

\begin{tabular}{lll}
\hline & 2006 & 2009 \\
\hline Dry stock (winter su) & 4676 & 4791 \\
Lambs produced/ha & 12.6 & 15.4 \\
Lamb carcase weight $^{1}(\mathrm{~kg})$ & 16.7 & 17.9 \\
& & \\
Dairy cows (wintering) & - & 330 \\
Grass sales & - & $187.5 \mathrm{t}$ \\
Whole crop cereal sales & - & $194 \mathrm{t}$ \\
& & \\
Cash Surplus $\left(\$ / \mathrm{ha}^{2}\right.$ & $\$ 269$ & $\$ 662$ \\
\hline
\end{tabular}

${ }^{1}$ Mean kill date 10 March in both years.

${ }^{2}$ Adjusted to the same lamb payment schedule 
feed demand. Grazing was sold to support cattle and cast-for-age ewes. Winter crop land was removed from grazing 1 month before normal practice. Weaning was delayed until January to continue to maximise demand of ewes and lambs. Further strategies were: to bring lambing date earlier, to use extra crop grown for winter dairy grazing, and to grow whole cereal and pasture silage crops for sale to dairy farmers.

\section{Outcomes of implementing improvement strategies}

Important features of this case study (Table 3) were the decreased overwintering stocking rate of the base enterprise, the income derived from sale of feed, and the increased lamb output. The farm took hold of the opportunities in other enterprises to address one of the key drivers within the business - pasture quality. The focus on that goal, rather than directly on productivity opened up options that both added profitability, and ultimately increased the lamb production from the enterprise.

The drivers of change in this case study were increasing profitability and improving resource utilisation. Proactive management was again a feature, as were new options for feed and land use that have become available in the region.

\section{Case Study 3: Improving deer farm productivity}

Deer farming is a relatively young and diverse industry in New Zealand. Research has established some best farming practices for deer (Casey 2003), yet the levels of uptake are extremely variable. Under pressure from competing land uses deer farmers have needed to become more efficient producers.

Focus on Deer, a MPI (MAF) Sustainable Farming Fund project (July 2005 to June 2008), engaged local farmers, regional councils, scientists, agribusiness

Table 5. Deer farm performance before and after the introduction of a self-feed wintering system for hinds, changes in stock class selection and the introduction of summer crops.

\begin{tabular}{lll}
\hline & 2007 & 2009 \\
Hinds & 1000 & 1100 \\
Weaners & 900 & 900 \\
MA Stags & 30 & 30 \\
Dairy Heifers & $150 \quad(21$ & 170 \\
& months) & \\
Dairy cows (wintering) & - & 300 \\
Stocking rate & 11.1 & 14.2 \\
Feed consumed (kg DM/ha) & 6640 & 8500 \\
Wintering costs & $\$ 39 / \mathrm{su}$ & $\$ 25 / \mathrm{su}$ \\
Cash Surplus (\$/ha) & $\$ 223$ & $\$ 491$ \\
\hline
\end{tabular}

${ }^{1}$ Deer prices adjusted to 2009 venison schedule and consultants in a project to implement sustainable improvements in environmental and productivity practice. The project provided a blend of demonstration and science to enhance the uptake of production and environmental practices in the deer industry. A northern Southland deer breeding and finishing farm of 370 ha running a stocking rate of $11.2 \mathrm{su} / \mathrm{ha}$ was chosen in July 2005. The region is characterised by cold winters with saturated soils and summer dry periods (Stevens \& Hickey 1989).

\section{Key improvements}

A key improvement made was the shift from "short grass" farming to "long grass" farming. This aimed to improve the early spring cover on the farm from between 800 and $1000 \mathrm{~kg} \mathrm{DM} / \mathrm{ha}$ to at least $1500 \mathrm{~kg}$ $\mathrm{DM} / \mathrm{ha}$. This would then enable more pasture growth, and lead to greater utilisation of pasture through increased stocking rate and per head performance of weaner deer, utilising the principle that "grass grows grass" and that feed intake can be improved at higher covers.

Many farmers are relatively conservative in their management of the environment. Gray et al. (2011) noted that $42 \%$ of farmers in a Hawke's Bay study used idling capacity (under-stocking) as a mitigation against drought, with only $20 \%$ maintaining a feed reserve, while $46 \%$ bought in supplements on the spot market as required. This suggests that feed management tends towards reactive rather than proactive, reducing the opportunity to capture potential when conditions were good.

Table 4. The objectives and strategies chosen by a deer farmer to improve productivity and profitability using opportunities presented by changing land use.

\begin{tabular}{ll}
\hline Objective & Strategy \\
\hline $\begin{array}{l}\text { Carry as many stock as } \\
\text { possible to control spring } \\
\text { flush }\end{array}$ & $\begin{array}{l}\text { Increase stocking rate } \\
\text { Add dairy grazers } \\
\text { Grow reliable winter crops } \\
\text { by sowing early } \\
\text { Minimise pasture damage } \\
\text { Self-feed silage pit for hinds } \\
\text { Increase area of crops for } \\
\text { other stock }\end{array}$ \\
$\begin{array}{l}\text { Minimise cost and labour } \\
\text { requirement }\end{array}$ & $\begin{array}{l}\text { Self-feed silage pit } \\
\text { Crops for Dairy grazers }\end{array}$ \\
$\begin{array}{l}\text { Stock come through in } \\
\text { prime condition }\end{array}$ & $\begin{array}{l}\text { Grass feeding to weaners } \\
\text { Self-feed silage for hinds }\end{array}$ \\
$\begin{array}{l}\text { Provide sufficient pasture } \\
\text { cover for maximum weaner for dairy grazers } \\
\text { growth from August }\end{array}$ & $\begin{array}{l}\text { Keep hinds on self-feed pit } \\
\text { until October }\end{array}$ \\
$\begin{array}{l}\text { Provide sufficient high qual- } \\
\text { ity feed during summer } \\
\text { to achieve high weaning } \\
\text { weights of calves regularly }\end{array}$ & $\begin{array}{l}\text { Summer crops, sown early } \\
\text { Whole crop cereal silage }\end{array}$ \\
\hline
\end{tabular}


Winter and late summer were identified as two key periods that significantly impacted on the overall productivity and profitability of the farm by reducing pasture cover below the targeted amount. Winter feed demand was well in excess of pasture growth, and overgrazing in late winter had the potential to further reduce pasture growth. Regular dry periods and occasional drought during the late summer were significant in restricting pasture supply to lactating hinds, thus compromising fawn weaning weight. Feed quality was a secondary objective that was integrated into the decision making process.

\section{Strategies to address production and profitability}

The strategies chosen to achieve a range of objectives (Table 4) were a mixture of feed and animal related measures, and were implemented at different stages over the 3 years of the programme. The first were taking on dairy grazers and the development of a selffeeding silage pit for hind wintering. Increasing the stocking rate only followed a period where the stocking rate of the core enterprise (deer farming) was reduced, to allow the increase in winter crop area, the integration of a summer crop and the harvest of whole crop cereal silage. These technologies needed to be implemented first before a long-term increase in core stocking rate could be achieved.

\section{Outcomes of implementing improvement strategies}

The outcomes of these strategies (Table 5) show a significant increase in stocking rate and feed consumed. The managements that led to this improvement started with the introduction of a self-feed silage pit for wintering hinds that meant that pastures were not damaged during winter and had higher covers in early spring. This improved pasture growth in late winter and early spring, resulting in greater weaner growth and more land for early crop sowing and silage making. Weaners were sold earlier as a result, reducing pressure on summer pastures. Early sowing of crops meant more reliable crop yields. More silage meant that a buffer of conserved feed was available if pasture growth was compromised.

Wintering costs were decreased and profitability increased with these changes, while the resultant system provided the resilience to maintain performance between years.

The opportunities taken in this case study were a combination of improving current performance, utilising the cash flow options of dairy grazing and taking control of feed supply and demand through proactive management. The major driver of change was declining profitability.

\section{Discussion}

The rise of dairying in southern New Zealand has created a number of opportunities, ranging from complete conversion to integrated cropping and dairy grazing options. The farmers of the region have responded in many different ways to engage in this change.

One opportunity that was identified for the region was dairy beef (McCraw 1992). Interestingly, Statistics New Zealand (2012) shows a relatively stable contribution of dairy to the beef industry in both Otago and Southland, as represented by the number of rising 1-year-old bulls. This number has fluctuated around 30000 since 1994, while the number of bull calves has risen from approximately 59000 in 1994, to 155000 in 2002 and 266000 in 2010. This may reflect the potential for soil damage if heavy beef animals are grazed on an annual basis, or a shift towards cross-bred dairy cows with less Friesian genetics. Dairy grazing, on the other hand is a winter activity, often restricted to a brassica crop which is then sown back to grass. This allows farmers to provide grazing, and to upgrade pastures at what is considered a relatively low cost, as the grazing pays for the renewal.

What continues to be evident in these case studies is the use of technology-based strategies to control production (Pittaway et al. 1992) in this region. Managerially oriented strategies, such as integrating dairy grazing, selling crop and pasture silage and using information such as feed quality testing, also continue to feature highly in the case studies.

Continuing to maintain strong family ownership has been a feature, though more flexible ownership structures such as corporate farming (including several NZ Dairy Farming Ltd farms (Kleyngeld \& Kleyngeld 1992)) and equity partnerships have also developed as a feature in southern New Zealand. This is both as a result of local sheep and beef farmers using the opportunity as off-farm investment and new farmers coming to the region with different views of ownership.

The strategies chosen all appear quite simple but require detailed understanding of both the individual farm system and scientific first principles to enable the implementation of those strategies. Farmers throughout southern New Zealand have engaged with the opportunities that changing land use has provided to remain profitable and to ensure the on-going future of their families on the land.

\section{REFERENCES}

Casey, M.J. 2003. The nutrition and management of deer on grazing systems. Grassland research and practice series 9: 126pp.

Dalley, D.E.; Geddes, T. 2012. Pasture growth and quality on Southland and Otago dairy farms. Proceedings of the New Zealand Grassland Association 74: 237-242. 
Davison, R. 2012. Domestic trends and measuring progress against the red meat sector strategy. Presentation to the Red Meat Sector conference 2012. http://www.beeflambnz.com/information/economicreports/ accessed August 2012.

Gray, D.I.; Reid, J.I.; Horne, D.J. 2011. The management of risk in a dryland environment. Proceedings of the New Zealand Grassland Association 73: 13-21.

Holmes, C.W.; Roche, J.R. 2007. Pastures and supplements for dairy production systems. In: Pasture and supplements for grazing animals. Eds. Rattray P.V.; Brookes, I.M.; Nicol, A.M. New Zealand Society of Animal Production Occasional Publication 14: 221-242.

Kleyngeld, M.; Kleyngeld, I. 1992. Conversion of an eastern Southland sheep farm to factory supply dairy pasture: changes and implications for production. Proceedings of the New Zealand Grassland Association 54: 15-17.

McCraw, A. 1992. Integrated bull beef with sheep in eastern Southland. Proceedings of the New Zealand Grassland Association 54: 27-30.

Ministry for Primary Industries. 2012. Farm monitoring report 2012 - National sheep and beef. http://www. mpi.govt.nz/news-resources/publications.aspx Accessed August 2012.
Pittaway, S.F.; Newman, D.L.; Anderson, G.A.; Saunders, L.S. 1992. Risk consideration and Southland farmers. Proceedings of the New Zealand Grassland Association 54: 11-14.

Rolhoff, M. 1992. A focus on the future of intensive sheep farming. Proceedings of the New Zealand Grassland Association 54: 95-98.

Smith L.C. 2012. Long term pasture growth patterns for Southland, New Zealand: 1978 to 2012. Proceedings of the New Zealand Grassland Association 74: 147152.

Statistics New Zealand. 2012. Agricultural statistics. Livestock numbers by regional council. http://www. stats.govt.nz/tools_and_services/tools/TableBuilder. aspx accessed August 2012.

Stevens, D.R.; Hickey, M.J. 1989. Comparative performance of 'Grasslands Matua' prairie grass and 'Grasslands Nui' ryegrass under a hard, infrequent grazing management. New Zealand Journal of Agricultural Research 32: 17-22.

Tarbotton, I.; Bell, P.; Mitchelmore, K.; Wilson, J. 2012. Network Project South Otago/Southland Region. Internal report DairyNZ, Newstead, Hamilton. 68 pp. 